https://doi.org/10.5817/NR2020-1-9

\section{Jaroslav Vávra jubilující}

V březnových dnech letošního roku se dožil záviděníhodného a požehnaného věku devadesáti let přední český literární vědec, vysokoškolský pedagog, překladatel a rusista $\mathrm{PhDr}$. Jaroslav Vávra, CSc.

Jde o jednoho $\mathrm{z}$ posledních veteránů poválečné generace literárněvědných rusistů, přímého pokračovatele předválečné tradice osobností, jako byl B. Mathesius, A. A. Vrzal, F. Wollman, J. Jirásek a další.

Jaroslav Vávra se narodil 21. 3. 1930 v Humpolci. Studoval na Reálném gymnáziu v Mariánských Lázních. Jako jeden z nejtalentovanějších studentů v Československu byl vybrán na středoškolská studia v Nimes ve Francii. Po roce se skupina československých studentů vrátila a Vávra zakončil stř̌edoškolská studia maturitou mezi nejlepšími.

Poté byl v roce 1949 přijat na Filozofickou fakultu Univerzity Karlovy obor ruština-čeština. Po absolutoriu $\mathrm{v}$ roce 1953 působil jako odborný asistent na Vysoké škole ruského jazyka a literatury v Praze, která byla tehdy zřízena, aby pokryla akutní potřebu rusistů $\mathrm{v}$ 50. letech minulého století. Na škole se za poměrně krátkou dobu její existence rozvinula další poválečná vlna vědeckovýzkumné práce v oboru rusistiky a bohemistiky. Po zrušení VŠRJL v letech 1959/196o dr. Vávra pracoval na ministerstvu školství, kde si prošel pozice od referenta až po ředitele odboru vysokých škol. Po prověrkách a čistkách v období normalizace po okupaci roku 1968 byl vyloučen z KSČ a musel z funkce odejít. Roku 1969 získal na FF UK titul PhDr. a následně od r. 1970 působil na FF UK jako jeden z největších znalců ruské a sovětské poezie 20. století.

Dlouhé období let 1970-1995 byl dr. Vávra vědeckým pracovníkem Filozofické fakulty Univerzity Karlovy, většinu doby jako vědecký pracovník literárněvědného oddělení katedry ruského jazyka a literatury. Zde obhájil i titul kandidáta věd. Překládal z ruštiny zejména beletrii a odbornou literaturu z oblasti literární vědy. ${ }^{1}$ Byl a je členem mnoha redakčních rad, expertních komisí a dalších odborných grémií.

Vávrovým celoživotním zájmem i osou jeho vědeckého a pedagogického působení byla zejména ruská poezie počátku 20. století. Oblíbenými autory byli třeba A.Blok, V.Brjusov, K. Balmont, S. Čornyj, Z. Gippius, N. Gumiljov, S. Jesenin, I. Severjanin. Bez politicky motivované nadstavby dokázal studentům tlumočit hloubku odkazu ruských básníků počátků éry sovětské literatury A. Achmatovové, M. Cvetajevové, V. Chlebnikova, O. Mandelštama, V. Majakovského a B. Pasternaka. V dobách, kdy se většina literárněvědných kolegů věnovala spíše próze nebo poezii 19. století, byl Vávra jedním z hlavních nositelů a tlumočníků odkazu moderní ruské poezie.

1 Např. [TARASENKOV 1972; JOKUBOV 1986] - oboje společně s Emilií Vávrovou. 
Letošní jubilant pravidelně přispíval do významných literárněvědných a odborných rusistických periodik u nás i v zahraničí. Jeho studie byly publikovány na stránkách časopisů Československá rusistika, Ruský jazyk, Slavia a dalších periodik a různých sborníků u nás i v zahraničí.

Je nutné připomenout jeho aktivitu v České asociaci rusistů. Byl zakládajícím členem ČAR, kde působil v různých funkcích a v letech 1990-2000 jako předseda asociace. Po roce 1990 zastával funkci místopředsedy Česko-ruské společnosti. Do dějin novodobé rusistiky je též zapsán jako jeden ze zakladatelů celosvětové Mezinárodní asociace učitelů ruského jazyka a literatury (MAPRJAL). Patřil mezi hlavní organizátory V. mezinárodního kongresu MAPRJAL - Slovo a slovesnost, který se konal v Praze. Pravidelně s MAPRJAL spolupracoval jako lektor i oblíbený průvodce na svých odborných exkurzích, prezentacích a zájezdech.

Velké ocenění patří dr. Vávrovi za šiření pozitivních kulturních hodnot a podporu porozumění mezi národy $\mathrm{v}$ pozici spoluzakladatele tradiční celostátní literární a recitační soutěže Puškinův památník. Jeho zanícení, schopnost povzbudit účastníky soutěže $\mathrm{v}$ lásce $\mathrm{k}$ literatuře a motivovat je $\mathrm{k}$ aktivnímu vnímání uměleckých hodnot a ve schopnosti je tlumočit a předávat publiku je pověstná. Poroty této soutěže vedl vždy profesionálně, s absolutní mírou nestrannosti a velkou citlivostí.
$\mathrm{V}$ oblasti popularizace a propagace světové, české a ruské poezie je možno připomenout, že v 6o. letech 20. století byl dr. Vávra jedním z protagonistů Cyklu poetických večerů v Televizním klubu na Smetanově nábřeží. V 9o. letech byl spoluautorem (spolu s Jiřím Klapkou) programu Písně frontového šoféra a dalších kulturních událostí, jež šírily v povědomí lidí lásku ke kvalitní poezii a jejímu přednesu.

Jako zcela mimořádné oceňují stovky studentů, které Vávra učil, jeho pedagogické schopnosti. Jeho lidskost, přesvědčivost, schopnost strhnout publikum, nadchnout ho pro poezii, primět zajímat se o poezii, přemýšlet o ní, zkrátka, mít poezii rád. Vávrův pedagogický projev působil úsporně, ale velmi hutně a obsažně. Vždy, když promluvil, nastalo $\mathrm{v}$ auditoriu ticho. Vyjadřoval se klidně, věcně, neteatrálně. Pro zdůraznění obsahu probírané látky přidal občas pohyb ruky, mírné gesto, kterým však dokázal podtrhnout to nejdůležitější. Pedagogů, kteří obrovským charizmatem při přednáškách a seminárích uměli strnout pro svůj obor, zase nebylo na rusistice tak mnoho. Vedle Vávry mezi ně $\mathrm{v}$ pražské rusistice patřili např. doc. Huňáček, doc. Jehlička, dr. Čížková nebo doc. Mathauserová a někteří další.

Z jeho monografí zaslouží bezesporu největší pozornost kniha Óda, elegie a balada $v$ ruské a sovětské poezii [VÁVRA 1990], která se stala ve své době jedním z mála obsahově bohatých zdrojů o ruské poezii. Zajímavá byla též Vávrova překladatelská činnost $\mathrm{v}$ široké per- 
spektivě od beletrie po vědeckou literaturu. $^{2}$

Dr. Vávra se aktivně podílel i na dalším širokém spektru rusistického bádání. Byl spoluautorem řady odborných sborníků, bibliografií, kompendií. ${ }^{3}$ Psal však nejen o ruské poezii moderní a klasické (napřr. o díle A.S. Puškina) ${ }^{4}$, ale i o ruské próze, kupř. o díle L. N. Tolstého. Široký okruh učitelů ruského jazyka zná J. Vávru jako skvělého přednášejícího a věrného účastníka celostátních seminářo pro učitele ruského jazyka.

I v pozdně seniorském věku zůstává J. Vávra věrný lektorské a osvětové činnosti. Velmi oblíbené jsou třeba jeho komentované vycházky a exkurze na Křivoklát a okolí a také jeho přednášky a články v regionálním tisku Středočeského kraje na kulturní a literární témata.

PhDr. Jaroslav Vávra, CSc., je mezi rusisty výjimečný. Výjimečný proto, že snoubí všechny nejlepší vlastnosti pravé osobnosti: je skvělý odborník ve svém oboru, je za všech okolností tvůrčím a přínosným kolegou a spolupracovníkem, umí strhujícím způsobem předávat své znalosti dalším a dalším generacím a přenášet vlastní nadšení pro obor svým posluchačům, je skvělý pedagog.

$\mathrm{V}$ neposlední řadě je Jaroslav Vávra i pro mladší generaci úžasným kamarádem a přítelem. Ani to není obvyklá vlastnost. J. Vávra má i ve svém věku

2 Např. [BIANKI 1956; BIANKI 1958], oboje jako spolupřekladatel.

3 Např. [KOŽEVNIKOVÁ, VÁVRA, CAMUTALIOVÁ 1984].

4 Např. doslov v [PUŠKIN 1975]. stále mladou duši. Nezkazí nikdy žádnou legraci, má noblesní smysl pro humor, je obdařen krásným sametovým barytonem a přednesem, který je neodmyslitelnou součástí jeho přednášek i přátelských setkání a posezení při sklenici vína nebo piva, téměř vždy doprovázených zpěvy francouzských, ruských a českých písní.

Je skvělé, že tyto vlastnosti Jaroslav Vávra dodnes aktivně a usilovně předává i svým vnoučatům a všem nám, kolegům a kamarádům, kteří jsou formálně o generaci mladší.

Blahopřejeme Jaroslavu Vávrovi ke krásnému životnímu jubileu. Děkujeme za jeho odbornou erudici, vnitřní životní sílu, laskavost, nadhled a moudrost. Za všechny kolegy bývalé i současné, za všechny studenty bývalé i současné, za všechny kamarády a kamarádky současné přeje mnoho další aktivních let, dobrou mysl a zdraví.

Fiř́ Klapka, Michail Odarčenko

\section{Bibliografie:}

BIANKI, V.V. (1956): Kotrmelec a jiné povídky. Praha.

BIANKI, V.V. (1958): Kotrmelec a jiné povídky. Praha.

JOKUBOV, O. (1986): Poklad ze Samarkandu. Praha.

KOŽEVNIKOVÁ, K., VÁVRA, J., CAMUTALIOVÁ, I. (1984): Ruská literatura $v$ českém překladu: antologie: určeno pro posl. fak. filozof. a pedagog. 1., 
Starší literatura a poezie: Část česká a ruská. Praha.

PUŠKIN, A. S. (1975): Eugen Oněgin. Praha.

TARASENKOV, D. A. (1972): Př́pad Kentaur. Praha.

VÁVRA, J. (1990): Óda, elegie a balada $v$ ruské a sovětské poezii. Praha.

https://doi.org/10.5817/NR2020-1-10

\section{Leskov podruhé v Brnĕ}

Druhé brněnské kolokvium - doktorská škola o Leskovovi - se konala 5.-6. listopadu 2019 (předtím Leskova vystř́idal Dostojevskij, z obou kolokvií byly vydány publikační výstupy ${ }^{1}$ ) pod názvem N.S. Leskov a tradice ruského románu ve světovém kontextu. Kolokvia se zúčastnili doktorandi a jejich učitelé a školitelé z České republiky, Ruska a Ukrajiny, mezi nimi editorka Leskovova díla a známí ruští leskovologové. Jazykem kolokvia byla hlavně ruština.

Již v roce 2017 pořádal Ústav slavistiky Filozofické fakulty Masarykovy univerzity $z$ iniciativy autora této zprávy $\mathrm{v}$ rámci tzv. doktorských škol první mezinárodní brněnské kolokvium o ruském spisovateli 19. století, dříve pozapomínaném, Nikolaji Semjonoviči Leskovovi (1831-1995), Současně byla

1 Viz [POSPÍŠIL 2018b; PAUČOVÁ, POSPÍŠIL 2019]. Viz naše zprávy [POSPÍŠIL 2018a; POSPÍŠIL 2018c; POSPÍŠIL 2019]. Dále [FEDOTOVA 2018]. tehdy v Brně založena virtuální Mezinárodní společnost N. S. Leskova, která si za cíl stanovila podporu leskovovského bádání, vytváření sítě leskovovských badatelů a celkově rozvoj leskovologie.

Jak jsme napsali $v$ prredmluvě $k$ prvnímu brněnskému svazku o Leskovovi, ruský spisovatel byl dlouho považován za outsidera, neúspěšného, podprůměrného realistického autora [POSPÍŠIL 2018b]. Nyní je sice situace jiná, ale román zůstává problémem Leskovovy tvorby dosud. V tomto ohledu je Leskov názorným př́ikladem. Jeho žánrové experimenty netřeba dokumentovat, stejně jako jeho individuální pojmenovávání literárních žánrů, včetně jejich orálního a lidového rázu (skaz, črta, vzpomínka, legenda, kronika, pohádka, rapsodie, obrázek podle skutečnosti, pozorování, pokusy, duchařský případ, povídka na hrobě, půlnoční vidění, heraldická kauza, bukolická povídka na historickém základě). ${ }^{2} \mathrm{~V}$ našich četných knihách a studiích, zejména v malé leskovovské monografii ${ }^{3}$, jsme došli $\mathrm{k}$ závěru, že v Leskovově tvorbě lze sledovat dvojí žánrový zlom a to vše se projevilo také ve skladbě druhého brněnského kolokvia o románu leskovovského typu. Leskov se vlastně celý život snažil vytvořit tradiční balzakovský román, ale to se mu nepř́liš dařilo; proto pod jeho rukama vznikaly

2 Viz naše monografie [POSPÍŠIL 1992a; POSPÍŠIL 1992b]. Viz také studii [POSPÍŠIL 2013].

3 Viz již naši diplomovou a rigorózní práci [POSPÍŠIL 1975a; POSPÍŠIL 1975b] a další knihy a studie uvedené jinde. 